\title{
BEZBEDNOSNA ZAŠTITA OBJEKATA OD POSEBNOG ZNAČAJA ZA ODBRANU
}

\author{
Dejan Ž. Nikolić \\ Vojska Srbije, Garda \\ Mitar Kovač* \\ Fakultet za projektni i inovacioni menadžment, Beograd \\ Vlada M. Mitić
}

Ministarstvo odbrane Republike Srbije, Uprava za strategijsko planiranje

\begin{abstract}
snovni zadatak službi za obezbeđenje objekata od posebnog značaja za odbranu je zaštita samih objekata od svih nepredviđenih događaja. Da bi se uspelo u tome, mora da postoji adekvatan sistem bezbednosne zaštite. Cilj rada je da prikaže potrebu za jedinstvenim pravnonormativni okvirom i definisanim objedinjenim merama bezbednosne zaštite objekata od posebnog značaja za odbranu.
\end{abstract}

Ključne reči: objekat od posebnog značaja za odbranu, zaštita objekata, bezbednosne mere zaštite

U poslednjih 50 godina u svetu, uprkos organizovanim službama bezbednosti, uništeno ili oštećeno je nekoliko desetina različitih objekata od značaja za odbranu. Da bi se država suprotstavila određenih subverzivnih aktivnosti, ona osniva specijalizovane ustanove i organizacije u okviru svog aparata radi vršenja zaštitne funkcije. Tako su, pored kontraobaveštajnih, obaveštajnih i drugih službi, vremenom nastale i službe obezbeđenja koje se bave zaštitom određenih ličnosti i objekata u kojima oni borave.

Organi i službe koje se bave poslovima zaštite objekata od posebnog značaja za odbranu, u obavezi su da stalno prate izvore, oblike, aktivnosti, indikatore koji su usmereni na njihovo ugrožavanje i preduzimaju mere radi sprečavanja neželjenih događaja.

Različite su prakse u postupanju, registrovanju propusta u radu na zaštiti objekata i procenjivanju njihovih negativnih posledica. U nameri da se odgovori na zahteve koje ova oblast nameće, na neusaglašena bezbednosna pitanja, prezentovan je pravno-normativni okvir i mere zaštite objekata od posebnog značaja za odbranu zemlje.

Težište u radu je dato na analizi pravno-normativni okvira zaštite objekata od posebnog značaja za odbranu zemlje u Republici Srbiji i utvrđivanje da li je ono u funkcionalnom i institucionalnom smislu primereno potrebama njihove zaštite u uslovima kada postoje savremene bezbednosne pretnje.

* Prof. dr Mitar Kovač je general-major u penziji. 


\section{Bezbednost i bezbednosna zaštita}

Savremeni izazovi, pretnje i rizici bezbednosti mogu biti: političke, ekonomske, ekološke ili čovekom izazvane društvene pretnje, odnosno mogu biti vojne i nevojne prirode. Zloupotreba novih tehnologija i dostignuća u oblasti informatike, eskalirajući terorizam, nacionalni i verski ekstremizam, finansijske recesije uticali su na potrebu jasnog definisanja standarda bezbednosti kojih se subjekti države i organizacije moraju pridržavati, a koji bi predstavljali i orijentir za utvrđivanje bezbednosnih ciljeva.

Za bezbednost se obično kaže da je nastala kada i sam čovek. Čovekova osnovna preokupacija je uvek bila, kako opstati (preživeti), kako se razvijati i kako obezbediti nastavak svoje vrste. Tek mnogo hiljada godina kasnije bezbednost se proširila na bezbednost čitave društvene zajednice, odnosno države pa i privrednih subjekata da bi danas shvatanje bezbednosti bilo mnogo širi pojam i od toga.

Bezbednost je opšti pojam, koji u srpskom jeziku izveden od reči „bez“ i „beda“, što u prevodu znači „bez nevolje“" $U$ teoriji bezbednosti postoje različita mišljenja i tumačenja pojma bezbednosti. U savremenim diskusijama o bezbednosti, kao ključnog pojma koji se odnosi na opstanak i razvoj pojedinca, društva, nacije i države, i dalje provejava problem identifikacije njegovog približnog sadržaja. Veliki broj teoretičara i dalje pri razmatranju pitanja bezbednosti podrazumevaju primenu vojne sile i njen uticaj na nacionalnu bezbednosti. Sam pojam može se posmatrati sa više aspekata. Najčešće se polazi od pretpostavke da se pod tim terminom podrazumeva određeno stanje, funkcija, organizacija, sistem ili sve to zajedno. ${ }^{2}$ Organizacija ujedinjenih nacija je 1986 . godine bezbednost definisala na sledeći način: „Bezbednost je stanje u kome države smatraju da nema opasnosti od vojnog napada, političkog pritiska ili ekonomske prisile, tako da mogu slobodno da se razvijaju i napreduju." Međutim tokom razvoja nauke o bezbednosti došlo se do zaključka da bezbednost nije samo stanje, već i proces.

Kao proces, bezbednost je povezana sa zaštitnom funkcijom države, gde ova aktivnost podrazumeva praktičnu primenu više konkretnih operacija i postupaka različitih državnih organa i agencija i / ili drugih subjekata koji učestvuju u ostvarivanju ove zaštitne funkcije. ${ }^{3}$ Bezbednost, kao aktivnost je neodvojivi atribut države, podrazumevajući obavljanje bezbednosnih zadataka radi zaštite određenih vrednosti.

Bezbednost, kao stanje u najširem smislu, predstavlja zaštićenost nekog dobra, vrednosti i tekovina društva. U političko-bezbednosnom smislu, obuhvata celokupnu zaštićenost države od svih vidova subverzivne delatnosti spoljašnjeg i unutrašnjeg neprijatelja i drugih štetnih delatnosti i uticaja. Između ostalog, bezbednost označava i službu bezbednosti, koja se može shvatiti kao skup aktivnosti i mera kojima se država štiti od aktuelnih ili potencijalnih neprijatelja, ili kao specijalizovana organizacija koja obavlja poslove, primenjuje mere, radnje i sredstva kojima se ostvaruje funkcija bezbednosti.

Slobodan Miletić bezbednost definiše kao "pravnim sredstvima ustanovljenim i obezbeđenim i kroz društvene odnose ugrađene, održavane i poboljšane uslove u državi koja omogućava efikasnu zaštitu države i njenih građana od svih (spoljnih i unutrašnjih) ilegal-

\footnotetext{
${ }^{1}$ Kostić, M., Koncept bezbednosti, Vojno delo, Beograd, broj 7/2016, str. 68.

2 Stajić, Lj., Osnovni bezbednosti, Policijska akademija, Beograd, 2003, str. 22.

${ }^{3}$ Stajić, Lj., Osnovni bezbednosti, Policijska akademija, Beograd, 2003, str. 12-13.
} 
nih akata (aktivnosti) koji imaju za cilj ugrožavanje ustavnog poretka, suverenitet, nezavisnost i teritorijalni integritet, rad državnih organa, privreda i društvene aktivnosti i ostvarivanje sloboda, prava i obaveze muškaraca i građana".

Na kompleksnost pojma bezbednost utiče i činjenica da sama diskusija o njoj uključuje u sebe i druge kategorije: strah (za fizički opstanak), znanje, odsustvo strukturalnog nasilja, mir, blagostanje i stabilnost, sve do slobode u svom univerzalnom smislu.

Zaštita predstavlja proces kome je cilj smanjenje ili neutralisanje rizika izazvanih potencijalnim dejstvom identifikovanih pretnji. ${ }^{4}$ Zaštita objekata koji se bezbednosno štite preduzima se u sklopu jedinstvenog sistema zaštite, shodno pozitivnim propisima i obuhvata usklađenu delatnost svih organa i službi bezbednosti, kao i drugih subjekata koji učestvuju u zaštiti, a koja preduzimaju svaka u okviru svoje nadležnosti, odgovarajuće radnje i mere u cilju potpunije zaštite tih objekata.

Osnovni zadatak specijalizovanih službi za obezbeđenje objekata od značaja za odbranu je kao zaštita objekata tako i zaštita integriteta ličnosti koje se štite i borave u istim. Da bi se uspelo u tome, mora da postoji adekvatan sistem bezbednosne zaštite.

Obaveštajne, bezbednosne i druge specijalizovane ustanove predstavljaju osnovu preventivne zaštite i većina njih deluje u skladu sa jasno definisanim strategijama nacionalne bezbednosti. Stručnost i efikasnost u vršenju tih poslova predstavljaju najznačajniji faktor ostvarenja bezbednosne zaštite.

Novije polje delatnosti specijalizovanih službi za obezbeđenje je saradnja sa pojedinim službama bezbednosti drugih zemalja, u cilju borbe protiv svih oblika ugrožavanja, a u interesu opšte bezbednosti. Osnovni preduslov postizanja višeg nivoa bezbednosne zaštite je, pre svega, usklađenost u planiranju i realizaciji zaštite, kroz koordinaciju svih elemenata u sistemu obezbeđenja.

Funkcionalna i kvalitetna bezbednosna zaštita objekata od značaja za odbranu mora da se sastoji od višestruko međusobno povezanih elemenata: normativno-pravne regulative u oblasti bezbednosne zaštite objekta od značaja za odbranu (uredbe i uputstva), usklađenosti u planiranju i realizaciji zaštite, kroz koordinaciju svih elemenata u sistemu bezbednosne zaštite, organizacijskog ustrojstva specijalizovanih službi za obezbeđenje i stalnog poboljšanja kadrovskih i tehničkih uslova rada specijalizovanih službi.

Iz navedenog može da se zaključi da bezbednosna zaštita objekata od značaja za odbranu predstavlja veoma složen zadatak za svaku specijalizovanu službu date zemlje.

\section{Pojmovno određenje objekata od posebnog značaja za odbranu}

U Republici Srbiji pod pojmom objekti od posebnog značaj za odbranu smatraju se objekti za koje se procenom utvrdi da bi njihovim oštećenjem ili uništenjem, odnosno otkrivanjem vrste, namene i lokacije, kod kojih se to čuva u tajnosti, mogle nastupiti teže posledice za odbranu i bezbednost. ${ }^{5}$ Često je deo ovih objekata namenjen za rad, život ili komandovanje, određenih ličnosti koji se štite posebnim merama kontraobaveštajne zaštite.

\footnotetext{
${ }^{4}$ Petrović, S., (2000), Kompjuterski kriminal, MUP Republike Srbije, Beograd, str. 377.

${ }^{5}$ Uredba o objektima i rejonima od posebnog značaja za odbranu Republike Srbije („Službeni glasnik RS“, broj 18/92).
} 
Zakonom o odbrani, u članu 67 se određuju objekti od posebnog značaja za odbranu zemlje u koje se ubrajaju: veliki tehničko-tehnološki sistemi, objekti u kojima se proizvode, skladište ili čuvaju predmeti ili vrše usluge za potrebe odbrane, objekti u kojima su smešteni državni organi $i$ pravna lica od posebnog značaja za odbranu zemlje, kao i određeni infrastrukturni objekti.

Vlada Republike Srbije je svojim podzakonskim aktom konkretizovala i definisala sledeće objekte kao objekte od značaja za odbranu: ${ }^{6}$

1. objekte u kojima su smešteni veliki tehničko-tehnološki sistemi, u skladu sa aktom o određivanju velikih tehničkih sistema od značaja za odbranu;

2. objekte u kojima se proizvode predmeti od značaja za odbranu zemlje;

3. objekte u kojima se skladište ili čuvaju predmeti od značaja za odbranu zemlje (pogonsko gorivo, hrana, otrovne materije, naoružanje i vojna oprema, lekovi i medicinska oprema itd.);

4. objekte u kojima se vrše usluge za potrebe odbrane (telekomunikacija, nadziranje vazdušnog saobraćaja, televizija, brodarstvo, zdravstvo, prehrambena industrija itd.);

5. infrastrukturne objekte (putevi, železnička infrastruktura, tuneli, mostovi, aerodromi, heliodromi, dalekovodi, naftovodi i gasovodi);

6. objekte u kojima je sedište državnih organa i organizacija obrazovanih u skladu sa zakonom;

7. objekte u kojima su smešteni državni organi i pravna lica od posebnog značaja za odbranu zemlje koji su određeni aktom nadležnog organa;

8. skloništa i druge javne objekte za zaštitu ljudi i materijalnih dobara i zaštitu životne sredine.

Nakon terorističkog napada od septembra 2001. godine i porasta opasnosti od asimetričnih pretnji u savremenim teorijskim analizama, ali i u praksi, sve je prisutniji izraz "kritična infrastruktura".

Australija je kritičnu infrastrukturu definisala na sledeći način: „Kritična infrastruktura predstavlja one fizičke objekte, lance snabdevanja, informacione tehnologije i komunikacione mreže, koje bi ako se unište ili na duže vreme onesposobile, mogle značajno uticati na društvo ili ekonomsko blagostanje nacije, ili bi uticale na sposobnost Australije da održi nacionalnu odbranu i obezbedi nacionalnu sigurnost". ${ }^{7}$

Postoje više definicija kritične infrastrukture, ali se sve one, u principu, odnosne na sredstva i imovinu, koja je ključna za neometano funkcionisanje ekonomije i društva. ${ }^{8}$

EU definiše takozvanu Evropsku kritičnu infrastrukturu kao onu koja se sastoji od onih fizičkih resursa, službi, uređaja, informacione tehnologije, sigurnosti mreža i infrastrukture, bezbednosne, ekonomske ili socijalne dobrobiti dve ili više članica.

Evropska komisija je identifikovala sledeće oblasti kritične infrastrukture: ${ }^{9}$

1. Energija,

2. Informacione i komunikacione tehnologije,

3. Voda,

\footnotetext{
${ }^{6}$ Odluka o vrstama investicionih objekata i prostornih i urbanističkih planova od značaja za odbranu („Službeni glasnik RS“, broj 85/2015).

7 "Critical Infrastructure Emergency Risk, Management and Assurance" Emergency Management Australia, A Division of The Attorney Generals Department, 2003.

${ }^{8}$ Škero, M., Ateljević, V., Zaštita kritične infrastrukture i osnovni elementi usklađivanja sa direktivom saveta Evrope 2008/114/ES, Vojno delo, Beograd, broj 3/2015, str. 192.

9 Jakovljević V., Gačić J.: Zaštita kritične infrastrukture u kriznim situacijama, MNK, Mladenovac, 2012., str. 283.
} 
4. Hrana,

5. Finansije,

6. Građanske vlasti,

7. Javni i pravni poredak i sigurnost,

8. Saobraćaj,

9. Hemijska i nuklearna postrojenja,

10. Kosmos,

11. Naučno istraživanje.

Generalno, definisanje okvira kritične infrastrukture u mnogim zemljama je različito i zavisi od raznih specifičnosti, počevši od političkih prilika do geografskih lokacija. ${ }^{10}$ Za lakše sagledavanje područja ovog pojma pregledno su dati okviri za nekoliko zemalja u tabeli 1.

Ako uporedimo sadržaj definicija kritične infrastrukture različitih zemalja u dokumentima kao i identifikovane oblasti kritične infrastrukture sa definicijom objekata značajnih za odbranu zemlje u Republici Srbiji kao i definisanim objektima od strane Vlade Republike Srbije možemo uočiti da je kritična infrastruktura opštiji pojam od pojma objekti od posebnog značaja za odbranu zemlje.

Do današnjeg dana Republika Srbija nije regulisala ovu značajnu oblast koja se odnosi na kritične infrastrukture. U okviru objekata od značaja za odbranu se prepoznaje veći deo ali i ne i celokupna oblast kritične infrastrukture. Time se može zaključiti da za deo kritične infrastrukture nisu pravno-normativno regulisane mere bezbednosti i zaštite tih objekata, što se može negativno odraziti na nacionalnu bezbednost Republike Srbije u slučaju određenih oblika krizna i vanrednih situacija.

Objekti od posebnog značaja za odbranu mogu biti vojni objekti i objekti od posebnog značaja za odbranu zemlje i rejoni tih objekata. ${ }^{11}$

$U$ vojne objekte spadaju, objekti ili delovi objekata u kojima su smešteni: uređena komandna mesta, centri veze, radio-relejna čvorišta, raketni položaji, važniji radarski i elektronski centri u sistemu komandovanja, osmatranja, obaveštavanja i javljanja, zaposednuti fortifikacijski objekti, vojni i mešoviti aerodromi, vojne luke (baze), opitni poligoni, laboratorije za izradu i ispitivanje novih sredstava ratne opreme i naoružanja, važnija skloništa naoružanja, municije, ubojnih sredstava, goriva i vojne opreme, prostorije u kojima se čuvaju planovi upotrebe Vojske Srbije i planovi mobilizacije, kripto-uređaji i šifre.

U objekte od posebnog značaja za odbranu zemlje, spadaju: objekti ili delovi objekata u kojima su smešteni veliki tehnički sistemi, preduzeća i druga pravna lica od posebnog interesa za odbranu zemlje; objekti u kojima se proizvode, skladište ili čuvaju predmeti ili vrše usluge od posebnog značaja za odbranu zemlje; investicioni objekti značajni za odbranu zemlje.

Pojedine objekte ili delove objekata, u okviru utvrđenih vrsta određuje ministar odbrane i o tome obaveštava odgovarajući državni organ, preduzeće i drugo pravno lice koje je vlasnik ili korisnik objekta, kao i službe bezbednosti i organe koji učestvuju u njihovoj zaštiti. Deo obaveza obuhvata i ograničenja izgradnje drugih objekata u blizini objekata od posebnog značaja za odbranu.

\footnotetext{
${ }^{10}$ Škero, M., Ateljević, V., Zaštita kritične infrastrukture i osnovni elementi usklađivanja sa direktivom saveta Evrope 2008/114/ES, Vojno delo, Beograd, broj 3/2015, str. 192.

${ }^{11}$ Odluka o određivanju vojnih i drugih objekata i rejona koji su zabranjeni za osmatranje, snimanje i pristup i o merama za njihovu zaštitu („Službeni list SRJ“, broj 11/96 i „Službeni list SCG“, broj 42/2005).
} 
Tabela 1 - Kritična infrastruktura različitih zemalja ${ }^{12}$

\begin{tabular}{|c|c|c|c|c|c|}
\hline Kanada & Velika Britanija & SAD & Nemačka & Norveška & Švajcarska \\
\hline \begin{tabular}{|l|}
\multicolumn{1}{|c|}{ ENERGIJA } \\
(objekti električne \\
i nuklearne ener- \\
gije, prirodni plin \\
i nafta, proizvodni \\
i transportni \\
sistemi) \\
\end{tabular} & ENERGIJA & ENERGIJA & $\begin{array}{l}\text { ENERGIJA } \\
\text { (električna, } \\
\text { nafta i plin) }\end{array}$ & ENERGIJA & $\begin{array}{l}\text { OBJEKTI } \\
\text { I SLUŽBE }\end{array}$ \\
\hline KOMUNIKACIJE & $\mid \begin{array}{c}\text { TELEKOMUNI- } \\
\text { KACIJE }\end{array}$ & \begin{tabular}{|l} 
INFORMACIJE \\
I TELEKOMU- \\
NIKACIJE
\end{tabular} & $\begin{array}{c}\text { TELEKOMUNI- } \\
\text { KACIJE I IN- } \\
\text { FORMACIONA } \\
\text { INFRASTRUK- } \\
\text { TURA }\end{array}$ & $\begin{array}{c}\text { SNABDEVANjE } \\
\text { NAFTOM } \\
\text { I PLINOM }\end{array}$ & $\begin{array}{l}\text { TELEKOMUNI- } \\
\text { KACIJE }\end{array}$ \\
\hline \begin{tabular}{|l|}
\multicolumn{1}{|c|}{ SERVISI } \\
(finansije, distri- \\
bucija hrane, \\
javno zdravstvo)
\end{tabular} & \begin{tabular}{|} 
ZDRAVSTVENE \\
SLUŽBE
\end{tabular} & $\begin{array}{c}\text { JAVNO } \\
\text { ZDRAVSTVO }\end{array}$ & $\begin{array}{c}\text { JAVNO } \\
\text { ZDRAVSTVo } \\
\text { (uključujući i } \\
\text { snabdevanje } \\
\text { pitkom vodom } \\
\text { i hranom) }\end{array}$ & $\begin{array}{c}\text { TELEKOMUNI- } \\
\text { KACIJA }\end{array}$ & $\begin{array}{l}\text { DISTRIBUCIJA } \\
\text { INFORMACIJA }\end{array}$ \\
\hline $\begin{array}{l}\text { TRANSPORT } \\
\text { (vazdušni, mor- } \\
\text { ski, kopneni) }\end{array}$ & FINANSIJE & HRANA & \begin{tabular}{|l|} 
BANKARSTVO, \\
FINANSIRANjE \\
I OSIGURANjE
\end{tabular} & $\begin{array}{c}\text { JAVNO } \\
\text { ZDRAVSTVO }\end{array}$ & $\begin{array}{c}\text { JAVNO } \\
\text { ZDRAVSTVO }\end{array}$ \\
\hline $\begin{array}{l}\text { SIGURNOST } \\
\text { (nuklearna sigur- } \\
\text { nost, službe } \\
\text { spašavanja, } \\
\text { hitne službe) }\end{array}$ & TRANSPORT & $\begin{array}{c}\text { POLjOPRIVRE- } \\
\text { DA }\end{array}$ & $\begin{array}{c}\text { TRANSPORTNI } \\
\text { SISTEMI }\end{array}$ & $\begin{array}{l}\text { BANKARSTVO } \\
\text { I FINANSIJE }\end{array}$ & HRANA \\
\hline \multirow[t]{6}{*}{\begin{tabular}{|l|}
\multicolumn{1}{|c|}{ VLADA } \\
(bitni vladini \\
objekti, službe \\
i informacioni \\
sistemi i mreže)
\end{tabular}} & $\begin{array}{l}\text { HITNE } \\
\text { SLUŽBE }\end{array}$ & $\begin{array}{l}\text { BANKARSTVO } \\
\text { I FINANSIJE }\end{array}$ & $\begin{array}{c}\text { HITNE I } \\
\text { SPASILAČKE } \\
\text { SLUŽBE }\end{array}$ & TRANSPORT & FINANSIJE \\
\hline & $\begin{array}{c}\text { CENTRALNA } \\
\text { VLAST }\end{array}$ & HITNE SLUŽBE & \begin{tabular}{|c|} 
VLASTI JAVNE \\
SLUŽBE \\
(uključujući \\
policiju, carinu i \\
oružane snage) \\
\end{tabular} & $\begin{array}{l}\text { SPASILAČKE } \\
\text { SLUŽBE }\end{array}$ & TRANSPORT \\
\hline & $\begin{array}{c}\text { VODA I } \\
\text { ODVODNjA }\end{array}$ & VLAST & & ODBRANA & $\begin{array}{c}\text { CIVILNA } \\
\text { ODBRANA }\end{array}$ \\
\hline & & $\begin{array}{c}\text { OSNOVNA } \\
\text { ODBRAMBENA } \\
\text { INDUSTRIJA }\end{array}$ & & POLICIJA & $\begin{array}{l}\text { ADMINISTRA- } \\
\text { CIJA }\end{array}$ \\
\hline & & VODA & & $\begin{array}{l}\text { DRUŠTVENA } \\
\text { SIGURNOST }\end{array}$ & $\begin{array}{c}\text { VOJNA } \\
\text { ODBRANA }\end{array}$ \\
\hline & & $\begin{array}{l}\text { HEMIJSKA } \\
\text { INDUSTRIJA } \\
\text { I OPASNE } \\
\text { MATERIJE }\end{array}$ & & & $\begin{array}{c}\text { SNABDEVANjE } \\
\text { VODOM }\end{array}$ \\
\hline
\end{tabular}

${ }^{12}$ Škero, M., Ateljević, V., Zaštita kritične infrastrukture i osnovni elementi usklađivanja sa direktivom saveta Evrope 2008/114/ES, Vojno delo, Beograd, broj 3/2015, str. 193. 


\section{Normativno pravna uređenost zaštite objekata od posebnog značaja za odbranu}

Značaj zaštite objekata od posebnog značaja za odbranu Republike Srbije uviđa se iz normativno-pravnog okvira koja definišu ovu oblast i predstavlja segment zaštite samih objekata. Sprovođenje poslova bezbednosti i odbrane zemlje samo po sebi je tajne prirode, a posebno zaštita objekata od posebnog značaja.

Sistemska pravno-normativna akta koja konkretnije uređuju zaštitu objekata proizilaze iz sledećih strategijsko-doktrinarnih dokumenata Republike Srbije:

- Strategija nacionalne bezbednosti Republike Srbije, kao polazni dokument, u poglavlju V precizno definiše Sistem nacionalne bezbednosti;

- Strategija odbrane konkretizuje sistem odbrane Republike Srbije, koji je deo sistema nacionalne bezbednosti;

- Doktrina Vojske Srbije, kao i Funkcionalne doktrine, elemenat bezbednost definišu kroz bezbednosne pripreme radi identifikacije indikatora ugrožavanja bezbednosti i potrebnih sposobnosti za zaštitu MO i VS i njenih delova od delovanja nosilaca svih oblika ugrožavanja bezbednosti.

Od sistemskih zakona koji definišu elemenat bezbednost, pre svega treba navesti Zakon o odbrani, koji u glavi II člana 20., kao bezbednosne poslove od značaja za odbranu zemlje, navedeni: opštebezbednosne, kontraobaveštajne i vojnopolicijski poslove.

Zakon o Vojsci Srbije, još konkretnije, sa aspekta zaštite tajnih podataka definiše da je dužnost pripadnika Vojske Srbije da čuva vojnu, službenu i državnu tajnu, za vreme službe, kao i po prestanku službe u periodu što je određeno zakonom kojim se uređuje zaštita tajnih podataka. Svi podaci vezani za objekte od posebnog značaja za odbranu zemlje predstavljaju tajne podatke.

Od ostalih sistemskih propisa, među najznačajnijim sa aspekta zaštite tajnih podataka u Republici Srbije, izdvajaju se Zakon o tajnosti podataka, Zakon o osnovama uređenja službi bezbednosti Republike Srbije, Zakon o VBA i VOA, kao i više podzakonskih akata.

Zakonom o odbrani, u članu 67. se propisuju i određuju objekti od posebnog značaja za odbranu zemlje u koje se ubrajaju: veliki tehničko-tehnološki sistemi, objekti u kojima se proizvode, skladište ili čuvaju predmeti ili vrše usluge za potrebe odbrane, objekti u kojima su smešteni državni organi i pravna lica od posebnog značaja za odbranu zemlje, kao i određeni infrastrukturni objekti.

Sledeća podzakonska akta, u skladu sa članom 25. Zakona o odbrani, članom 104. Zakona o tajnosti podataka, članom 10. stav 1. tačka 7. Zakonom o Policiji, članom 2. i 53. stav 1. Zakona o Vojsci Srbije, članom 5. i 11. Zakona o osnovama uređenja službi bezbednosti Republike Srbije, članom 2. Zakona o Bezbednosno-informativnoj agenciji i članom 6. Zakona o Vojnobezbednosnoj agenciji i Vojnoobaveštajnoj agenciji u oblasti zaštite objekata od posebnog značaja, se odnose na kriterijume za zaštitu objekata od posebnog značaja:

- Uredba o oblastima naučnih i drugih istraživanja značajnih za odbranu zemlje i o postupku i uslovima za izdavanje odobrenja za vršenje tih istraživanja zajedno sa stranim licima ili za potrebe stranih lica.

- Uredba o postupku za izdavanje odobrenja za snimanje iz vazduha teritorije Savezne Republike Jugoslavije i za izdavanje kartografskih i drugih publikacija. 
- Uredba o određivanju poslova bezbednosne zaštite određenih lica i objekata.

- Uredba o kriterijumima za utvrđivanje podataka značajnih za odbranu zemlje koji se moraju čuvati kao državna ili službena tajna i o utvrđivanju zadataka i poslova od posebnog značaja za odbranu zemlje koje treba štititi primenom posebnih mera bezbednosti

- Odluka o određivanju vojnih i drugih objekata i rejona koji su zabranjeni za osmatranje, snimanje i pristup i o merama njihove zaštite.

- Odluka o objektima od posebnog značaja za odbranu.

- Odluka o određivanju podataka koje ne mogu sadržavati kartografske i druge publikacije.

- Odluka o pravima i dužnostima organa pri izgradnji vojnih i drugih objekata od posebnog značaja za odbranu zemlje.

Navedenim podzakonskim aktima (Uredba i Pravilnik), treba dodati i dva Rešenja kojima se određuju poslovi i zadaci od posebnog interesa za odbranu zemlje. Radi se o Rešenju o utvrđivanju zadataka i poslova od posebnog značaja za odbranu zemlje u Saveznom ministarstvu za odbranu koje treba štititi posebnim merama bezbednosti i Rešenju o utvrđivanju podataka od interesa za odbranu zemlje koji se smatraju tajnim podacima iz delokruga Saveznog ministarstva za odbranu i o određivanju mera i postupaka za njihovu zaštitu.

Pored navedenih dokumenata, postoji i veliki broj pravilnika i naređenja kojima se reguliše, konkretizuje rad na objektima u skladu sa već pomenutim zakonima i drugim aktima.

Zbog svog značaja detaljnije će biti obrađena Odluka o određivanju vojnih i drugih objekata i rejona koji su zabranjeni za osmatranje, snimanje i pristup i o merama za njihovu zaštitu. Naime Odluka određuje vojne objekte i objekte od posebnog značaja za odbranu zemlje kao i rejone tih objekata koji su zabranjeni za osmatranje, snimanje i pristup, propisuju se mere za njihovu zaštitu kao i način održavanja zabrane osmatranja, snimanja i pristupa tim objektima i rejonima.

Odlukom se mere zaštite objekata i rejona objekata preduzimaju kao mere fizičkog obezbeđenja, mere tehničke zaštite, opšte mere bezbednosti i mere kontraobaveštajne zaštite i iste su detaljno obrazložene u tački 5 . navedene odluke. Mere zaštite objekata i rejona preduzimaju se neprekidno i organizuju se u svim fazama planiranja, projektovanja, izgradnje i korišćenja objekata.

Jedna od definisanih mera je i zabrana privatnih poseta na radnom mestu licima zaposlenim u objektima ili delovima objekata. Starešina nadležne vojne komande ili ovlašćeno lice nadležnog organa određuje posebnu prostoriju za privatne posete, koja se, po pravilu, nalazi van kruga objekta.

Pristup objektima, odnosno delovima objekata i ulaz u te objekte dozvoljeni su, po pravilu, samo licima stalno zaposlenim u njima, a ostalim licima - samo po službenom poslu na osnovu dozvole koju izdaje starešina nadležne vojne komande ili ovlašćeno lice nadležnog organa.

Odlukom se definiše označavanje i obeležavanje zabrane osmatranja i snimanja objekata i rejona i pristupa objektima i rejonima čija se lokacija čuva u tajnosti.

Na kraju ovom odlukom ministar odbrane je ovlastio Generalštab VS, za sprovođenje postupka i izdavanje odobrenja za posete i boravak stranaca i drugih pravnih lica u objektima Vojske Srbije, koji su zabranjeni za osmatranje, snimanje i pristup.

Od pravno-normativnih akata značajna je i Uredba o određivanju poslova bezbednosne zaštite određenih lica i objekta, te će i ona biti detaljno obrađena. Naime Uredba od- 
ređuje poslove bezbednosne zaštite određenih objekata u zemlji i inostranstvu, koje neposredno vrše ministarstvo nadležno za unutrašnje poslove, Bezbednosno-informativna agencija (u daljem tekstu BIA), Vojnobezbednosna agencija (u daljem tekstu VBA), Vojna policija $i$ jedinice Vojske Srbije.

Bezbednosna zaštita određenih lica i objekata u zemlji i inostranstvu uredbom se pojedinačno određuje i to za lica: predsednika Republike; predsednika Narodne skupštine; predsednika Vlade; ministra spoljnih poslova; ministra odbrane; ministra unutrašnjih poslova; načelnika Generalštaba Vojske Srbije; direktora Bezbednosno-informativne agencije; direktora Vojnobezbednosne agencije; direktora Vojnoobaveštajne agencije; direktora policije; strane državnike-nosioce najviših državnih funkcija tokom službenih poseta Republici Srbiji; nosioci najviših pravosudnih funkcija i drugi državni funkcioneri u zavisnosti od procene ugroženosti, a po preporuci Biroa za koordinaciju rada službi bezbednosti.

Za objekte: Narodne skupštine; Generalnog sekretarijata predsednika Republike; Vladu; ministarstva; druge objekte koje koriste lica iz uredbe.

\section{Mere zaštite objekata od posebnog značaja za odbranu}

Prema jednoj od definicija bezbednosna zaštita objekata bi predstavlja pravnim propisima predviđen i uređen delokrug nadležnosti, prava i dužnosti subjekata bezbednosti jedne države, koji sprovode mere, radnje i postupke, sa ciljem da se obezbedi najviši stepen zaštite određenih objekata, odnosno predstavlja celokupnu delatnost kojom se sprečava i suzbija pojava ugrožavanja - pretnje određenim objekata koje se štite.

Bezbednosna zaštita objekata, koje koriste određene ličnosti koje se štite, odvija se preventivno i represivno u odnosu na konkretne oblike ugrožavanja objekta. Preventivna aktivnost je stalna, dok je represivna nepredvidiva i zavisi od razvoja konfrontacije na licu mesta.

Mere zaštite objekata i rejona objekata preduzimaju se u skladu sa:

- procenom bezbednosne situacije šireg rejona i mikrolokacije objekata, ispoljenog interesovanja nepozvanih lica, eventualno otkrivenih podataka o objektu, uticaja promena radne snage, tranzita stranaca i drugih činilaca koji mogu imati uticaja na zaštitu objekata;

- utvrđivanjem značaja objekata sa stanovišta odbrane i bezbednosti zemlje, radi određivanja odgovarajućih mera zaštite;

- određivanjem vrste tajne, stepena tajnosti i tajnih (šifrovanih) naziva pod kojima se vodi tehnička dokumentacija objekata i koji se obavezno primenjuju u prepisci i u toku izvođenja radova na objektu.

Pravno-normativna akta jedinstveno ne regulišu mere zaštite objekata i rejona objekata. Ako se uzmu sve definisane mere različitih pravno-normativnim akta iste bi se mogle grupisati u:

Opšte mere zaštite koje bih obuhvatile: procenu značaja podataka i određivanje vrste tajne, stepena tajnosti i mera njihove zaštite od trenutka njihovog nastanka, određivanje prostorija za rad i uslova i načina rada, izbor lica koja mogu biti upoznata s tajnim podacima, način čuvanja i korišćenja tajnih podataka, zabranu neovlašćenim licima pristupa objektima i ulaska u objekte od posebnog značaja za odbranu zemlje, zabranu neovlašćenim licima da snimaju tajne podatke i unose foto-aparate i druga tehnička sredstva za snimanje u objekte i prostorije u kojima se nalaze tajni podaci, zabranu izlaganja i prikazivanja neovlašćenim licima tajnih 
borbenih i drugih materijalnih sredstava i saopštavanje podataka o takvim sredstvima, određivanje načina i sredstava kojima se mogu prenositi tajni podaci, organizovanje fizičkog obezbeđenja i primenjivanje tehničkih i drugih mera zaštite tajnih podataka i prostorija za čuvanje tajnih podataka, zabranu razgovora o tajnim podacima ako njihova tajnost nije zaštićena, zabranu publikovanja tajnih podataka i kontrolu sprovođenja propisanih mera zaštite.

Posebne mere zaštite koje bih obuhvatile: vođenje posebne evidencije o dokumentima i o licima koja su ih koristila, određivanje tajnih naziva, čuvanje podataka u čeličnim kasama, obezbeđivanje prostorija u kojima se čuvaju podaci stražom ili drugim organima unutrašnje službe, utvrđivanje broja primeraka tajnih akata, stavljanje numeracije na svaki primerak ispod oznake tajnosti i određivanje korisnika podataka, pismeno uputstvo na dokumentu o tome je li dopušteno njegovo prepisivanje, umnožavanje, fotografisanje ili pravljenje izvoda, komisijsko uništavanje i koncepata, pribeleški, indiga, matrica itd., prenošenje podataka kurirom, specijalnim kurirom uz oružanu pratnju ili primenu sredstava tehničke zaštite, davanje pismene izjave o upoznavanju sa podacima koji predstavljaju državnu tajnu, pismenu primopredaju dužnosti između lica koja rukuju podacima ili in čuvaju, i primena mera kriptozaštite pri prenošenju tehničkim sredstvima veza podataka koji su državna ili službena tajna.

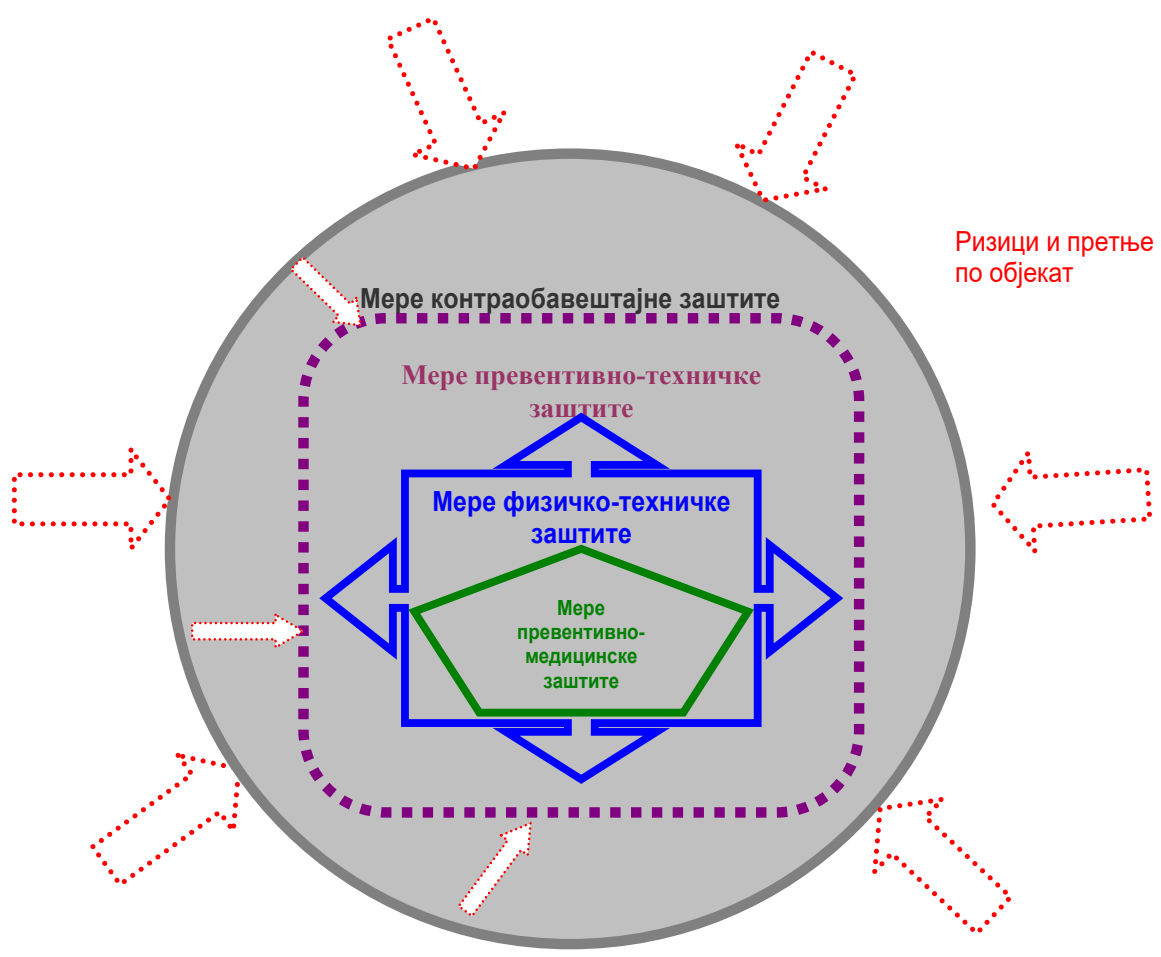

Slika 1 - Mere bezbednosne zaštite objekata od posebnog značaja za odbranu 
Pod poslovima bezbednosne zaštite ${ }^{13}$ podrazumevaju se:

- mere kontraobaveštajne zaštite;

- preventivno-bezbednosne mere;

- mere preventivno tehničke zaštite;

- mere fizičke zaštite;

- mere preventivno medicinske zaštite.

Mere kontraobaveštajne zaštite obezbeđenja lica i objekata predstavljaju skup poslova, zadataka i aktivnosti koji se preduzimaju sa ciljem sprečavanja nastanka štete, odnosno mere koje se odnose na ostvarivanje bezbednosti.

Mere kontraobaveštajne zaštite obuhvataju: ${ }^{14}$

- otkrivanje indikatora i blagovremeno onemogućavanje terorističke, ekstremističke, obaveštajne i druge subverzivne delatnosti stranih obaveštajnih službi, organizacija i lica usmerenih na ugrožavanje „štićenih lica i objekata“;

- učešće u proceni, predlaganju, propisivanju i realizaciji mera kontraobaveštajne zaštite, kao i u njihovom usklađivanju sa merama bezbednosne zaštite;

- primenjivanje mera protivprislušne zaštite;

- vršenje bezbednosnih provera po zahtevu rukovodioca objekta bezbednosne zaštite, za lica koja se primaju na rad, postavljaju ili raspoređuju na mesta rada i poslove koji se kontraobaveštajno štite;

- vršenje kontraobaveštajne zaštite radnih mesta i poslova u saradnji sa rukovodiocem objekata bezbednosne zaštite.

Mere preventivno-tehničke zaštite predstavljaju skup poslova, zadataka i aktivnosti koji se preduzimaju radi otkrivanja i uklanjanja minsko-eksplozivnih, zapaljivih, radioaktivnih i drugih opasnih materija, ustanovljavanja i otklanjanja tehničkih neispravnosti na uređajima i instalacijama i sprečavanja tajnog ili nasilnog ulaska u objekte i prostorije, kao i funkcionisanja zaštićenog sistema veza.

Pored navedenog, neophodna je i primena preventivnih bezbednosnih mera koja obuhvata i učešće u izradi procene stanja ugroženosti objekata bezbednosne zaštite, u saradnji sa drugim službama bezbednosti i rukovodiocem objekta bezbednosne zaštite kao i pružanja stručne pomoći na utvrđivanju načina čuvanja i korišćenja tajnih podataka i dokumenata i zaštite poverljivih komunikacija.

Mora se imati u vidu i da su fizičko-tehničke mere zaštite tajnih podataka i informacija deo opštih i posebnih mera zaštite objekata i tajnosti podataka koje se preduzimaju radi sprečavanja nastanka štete, odnosno mere koje se odnose na ostvarivanje fizičko-tehničke bezbednosti tajnih podataka i stranih tajnih podataka, obezbeđenja lica i objekata od posebnog značaja.

Fizičko-tehničke mere zaštite objekata od posebnog značaja za odbranu i tajnih podataka obuhvataju: ${ }^{16,17}$

- fizičku zaštitu određenih objekata koje lice koristi stalno ili povremeno;

\footnotetext{
${ }^{13}$ Uredba o određivanju poslova bezbednosne zaštite određenih lica i objekata („Službeni glasnik RS“, broj 72/2010).

${ }^{14}$ Odluka o određivanju vojnih i drugih objekata i rejona koji su zabranjeni za osmatranje, snimanje i pristup i o merama za njihovu zaštitu („Službeni list SRJ“, broj 11/96 i „Službeni list SCG“, broj 42/2005).

${ }^{15}$ Z. Gajić, M. Miladinović, Zaštita podataka u integrisanom telekomunikaciono-informacionom sistemu MO i VS, Stručni rad-ŠNO, VŠ, 2010, str. 24.

${ }^{16}$ Uredba o određivanju poslova bezbednosne zaštite određenih lica i objekata („Službeni glasnik RS“, broj 72/2010).

${ }^{17}$ Uredba o posebnim merama fizičko-tehničke zaštite tajnih podataka („Službeni glasnik RS“, broj 97/2011).
} 
- određivanje povoljnog položaja lokacije prostorija gde se vrši obrada tajnih podataka i informacija u okviru zgrade, odnosno gde je potrebno voditi računa o položaju sprata, strani sveta, daljini dalekovoda, gasovoda, emisiji štetnih gasova iz fabrike, vrsti instalacija u zgradi, i sl.

- zaštitu osetljivih prostorija i objekata rešetkama, specijalnim bravama (elektronske i šifro-brave), žičanim ogradama, prijavnom i čuvarskom službom,

- ugradnju alarmnih uređaja i video nadzora u posebno značajnim prostorijama,

- zaštitu prostorija i zgrada od požara, poplava, eksplozija, građanskih nemira,

- uvođenje identifikacionih kartica za zaposlena lica,

- mere zaštite od kompromitujućih elektromagnetnih zračenja (KEMZ)77,

- mere zaštite tajnih podataka u Tkl sistemima,

- mere zaštite tajnih podataka na računarskim mrežama kao što su identifikacija korisnika mreže, autentifikacija, bezbednost tajnih podataka koji se prenose putem računarske mreže (kriptografska metoda) i

- kvalitet, kontrola ispravnosti i redovno servisiranje tehničkih sredstava koja se koriste u procesu obrade podataka i informacija.

Preventivno-medicinske zaštite obezbeđenja lica i objekata predstavljaju skup poslova, zadataka i aktivnosti koji se preduzimaju sa ciljem pronalaženja i otklanjanja mikrobioloških, hemijskih i radioloških materija, štetnih po zdravlje i život određene ličnosti i obuhvataju:

- sprovođenje sanitarno-tehničkih pregleda određenih objekata i osoblja koje radi u objektima - kontrolu zdravstvene ispravnosti i kvaliteta prehrambenih artikala, vode i vazduha;

- kontrolu higijene transporta i skladištenja životnih namirnica;

- preduzimanje mera i obezbeđivanje adekvatne i pravovremene zdravstvene zaštite lica.

Može se zaključiti da mere bezbednosne zaštite obezbeđenja lica i objekata predstavljaju skup poslova, zadataka i aktivnosti koji se preduzimaju sa ciljem sprečavanja nastanka štete, odnosno mere koje se odnose na ostvarivanje bezbednosti.

Organ nadležan za bezbednosnu zaštitu na osnovu propisa koji uređuju ovu oblast, određuje koje će se mere bezbednosne zaštite (vrsta, obim, stepen) preduzimati za određeni objekat bezbednosne zaštite.

\section{Zaključak}

Može se zaključiti da danas ne postoje zakonski propisi koji objedinjeno i jedinstveno regulišu organizaciju i zadatke službe za obezbeđenje lica i objekata, tj. koji bi jedinstveno pravno regulisali ovu oblast. Istorija je pokazala da normativno-pravna regulativa u oblasti bezbednosne zaštite određenih objekta (uredbe i uputstva) ${ }^{18}$ je jedan od elemenata koji utiče na funkcionalnu i kvalitetnu bezbednosnu zaštitu određenih objekata.

Veliki je broj dokumenata, deo njih dosta vremenski „starih“, možda delimično i prevaziđenih što usložava sprovođenje istih. Zaštita imovine, lica i poslovanja, danas pre svega u velikim tehničkim sistemima-preduzeća od posebnog značaja za odbranu zemlje, ostvaruje se organizovanjem sopstvenih službi obezbeđenja, angažovanjem specijalizovanih preduzeća i agencija koja su registrovana da pružaju usluge obezbeđenja ili kombinovano.

\footnotetext{
${ }^{18}$ Belić M, Vasić M., Istorisjko-pravni aspekt poslova obezbeđenje određenih ličnosti i objekat, Bezbednost, Beograd, 1-2/2009, str. 112.
} 
Neophodno je istaći i da neusaglašenost terminoloških određenja u ovoj oblasti u „najstarijim“ dokumentima, normativima, dovodi do konfuzije i zbunjivanja čak i onih koji se bave navedenom strukom. Doktrine poznaju bezbednosno obezbeđenje, a u drugoj literaturi se naglašava bezbednosna zaštita koje nema u doktrinama i sl.

Zaštita, obezbeđenja, lica, objekata i tajnih podataka definitivno je jedno od najznačajnijih i najdelikatnijih izazova i rizika sa kojima se susreću svi subjekti bezbednosnog obezbeđenja u Republici Srbiji. Zakonom o odbrani i Zakonom o tajnosti podataka postavljeni su pravni okviri zaštite obezbeđenja lica, objekata i tajnih podataka u MO i VS i drugim državnim organima.

Ukoliko se projektovanju zaštite objekata od posebnog značaja za odbranu u Republici Srbiji pa samim tim i u MO i VS, ne pokloni dužna pažnja od samog početka razvoja, pa kroz svaki sledeći korak do konačne instalacije, zaštita će u velikoj meri biti ugrožena.

Realno, niko ne može da nam garantuje apsolutnu zaštitu, jer ma koliko neki sistem bude napravljen tehnički savršenim, njega ipak koriste ljudi. Ljudski faktor je i dalje jedno od ključnih mesta gde „bezbednost postaje kritična tačka“.

Republika Srbija bi trebala prvo da usvoji zakon o kritičnim infrastrukturama. ${ }^{19} \mathrm{Na}$ taj način, pored podizanja nivoa interoperabilnosti Republike Srbije sa državama EU, bi bio udaren temelj regulisanja i značajne oblasti vezane za bezbednosnu zaštitu objekata od značaja za odbranu zemlje, koja do danas nije adekvatno regulisana.

\section{Literatura}

[1] Kostić, M., Koncept bezbednosti, Vojno delo, Beograd, broj 7/2016, str. 68.

[2] Stajić, Lj., Osnovni bezbednosti, Policijska akademija, Beograd, 2003.

[3] Uredba o objektima i rejonima od posebnog značaja za odbranu Republike Srbije („Službeni list RS“", broj 18/92).

[4] Odluka o vrstama investicionih objekata i prostornih i urbanističkih planova od značaja za odbranu (Službeni glasnik RS, broj 85/2015).

[5] „Critical Infrastructure Emergency Risk, Management and Assurance”, Emergency Management Australia, A Division of The Attorney Generals Department, 2003.

[6] Škero, M., Ateljević, V., Zaštita kritične infrastrukture i osnovni elementi usklađivanja sa direktivom saveta Evrope 2008/114/ES, Vojno delo, Beograd, broj 3/2015, str. 192.

[7] Jakovljević V., Gačić J.: Zaštita kritične infrastrukture u kriznim situacijama, MNK, Mladenovac, 2012, str. 283.

[8] Odluka o određivanju vojnih i drugih objekata i rejona koji su zabranjeni za osmatranje, snimanje i pristup i o merama za njihovu zaštitu (Službeni list SRJ, broj 11/96 i Službeni list SCG, broj 42/2005).

[9] Uredba o određivanju poslova bezbednosne zaštite određenih lica i objekata (Službeni glasnik RS, broj 72/2010).

[10] Z. Gajić, M. Miladinović, Zaštita podataka u integrisanom telekomunikaciono-informacionom sistemu MO i VS, Stručni rad-ŠNO, VŠ, 2010, str. 24.

[11] Uredba o posebnim merama fizičko-tehničke zaštite tajnih podataka (Službeni glasnik RS, broj 97/2011).

[12] Belić M, Vasić M., Istorisjko-pravni aspekt poslova obezbeđenje određenih ličnosti i objekat, Bezbednost, Beograd, 1-2/2009, str. 105.

[13] Simić D., Nauka o bezbednosti: savremeni pristup bezbednosti, Službeni list SRJ, Beograd, 2002.

\footnotetext{
${ }^{19}$ Škero, M., Ateljević, V., Zaštita kritične infrastrukture i osnovni elementi usklađivanja sa direktivom saveta Evrope 2008/114/ES, Vojno delo, Beograd, broj 3/2015, str. 207.
} 